\title{
SELECTED TASKS OF CUSTOMER SERVICE MANAGEMENT IN THE LOGISTICS OF TRANSPORT COMPANIES
}

\begin{abstract}
The article presents research results of selected tasks of management of logistic customer service in enterprises of commercial cargo motor transport enterprises, with particular emphasis on the number of logistic customer service standards and customer expectations regarding the level of this service. The survey was conducted among 147 enterprises of commercial cargo motor transport operating in the Silesian Voivodeship. Afterwards, taking into account the entirety of the conducted research procedure, based on the collected primary data, an attempt was made to examine the dependence of selected areas of logistic customer service, occurring in the surveyed cargo transport companies in the Silesian Voivodeship, on the size of these entities.
\end{abstract}

Keywords: management, logistic customer service, transport company

\section{Introduction}

In the dynamically changing economic environment, many of the previous determinants of business success have diminished, and current development trends of many business entities are focused on the management of buyers in logistics. In the area of customer service management in enterprise logistics, a complex model should be adopted, including appropriate service standards and procedures ensuring correct and systematic measurement of this service level taking into account customer expectations.

The aim of this article is to present the results of research on selected tasks of logistic management of customer service in enterprises of commercial cargo motor transport, with particular emphasis on the number of logistic customer service standards and customer expectations regarding the level of this service. 


\section{Challenges of customer service management in logistics}

Currently observed in enterprises, shifting interest in raising product quality, lowering prices or territorial availability of products in the direction of precise defining factors determining professional logistic service, are discussed by R.H. Ballou $^{1}$, D.J. Bowersox, D. J. Closs and M.B. Cooper², M. Christopher ${ }^{3}$, D. Kempny ${ }^{4}$, D. Kisperska-Moroń ${ }^{5}$ or M. Kramarz ${ }^{6}$.

M. Chaberek ${ }^{7}$ S. Chopra and P. Meindl ${ }^{8}$, S. Cook ${ }^{9}$ associate the service of buyers in logistics with logistic support, which is the culmination of the basic process related to the production and delivery of goods or services. In this sense, logistic service which ensures that the specified good, in a specified quantity, at a certain time, of a certain quality, while maintaining the costs accepted by the consumer, will be at the recipient's, providing a customer service that determines the output of the logistic system process of satisfying basic needs. Therefore, the authors do not indicate spontaneous logistic customer service, but always connected with the basic process of producing goods and services aimed at satisfying specific needs.

As part of customer service management ${ }^{10}$, key logistics activity synchronizes all company activities towards the implementation of tasks such as ${ }^{11}$ :

- defining the wishes and needs of the consumer in the light of the experience of services;

- defining the service as a response to the customer's request;

- supply of the desired level of services.

With regard to all business entities, the postulate of service in logistics is similar: the use of methods and tools to gain market, satisfactory to the customer, profitable and the appropriate quality of services provided. Therefore, the logistic service mechanism focuses the useful and necessary attributes of economic life in the competitive economy, in particular by stating the optimal level of service and its quality as well as the effectiveness of the activities carried out. For enterprises, the basic task is to establish proper customer service standards based on measurement of relationships between alternative customer service levels and the costs of their

1 R.H. Ballou, Business Logistics: Supply Chain Management, Prentice Hall, United Kingdom 2003.

2 D.J. Bowersox, D.J. Closs, M.B. Cooper, Supply Chain Logistics Management, McGraw Hill, United Kingdom 2009.

3 M. Christopher, Logistics \& Supply Chain Management, Financial Times Prentice Hall, Harlow 2011.

4 D. Kempny, Logistyczna obstuga klienta, PWE, Warsaw 2001.

5 D. Kisperska-Moroń, Logistics customer service levels in Poland: changes between 1993 and 2001, International Journal of Production Economics 2005, 93-94, p. 121-128.

6 M. Kramarz, Elementy logistyczne obstugi klienta w sieciach dystrybucji, Difin Publisher, Warsaw 2014.

7 M. Chaberek, Makro-i mikroekonomiczne aspekty wsparcia logistycznego, University of Gdańsk Publisher, Gdańsk 2002.

8 S. Chopra, P. Meindl, Supply Chain Management: Strategy, Planning, and Operation, Person Prentice Hall, New Jersey 2009.

9 S. Cook, Customer Care Excellence. How to Create an Effective Customer Focus, Kogan Page Ltd., London 2002.

10 B. Nogalski, R. Ronkowski, Wspótczesne przedsiębiorstwo. Problemy funkcjonowania i zatrudniania, TNOiK, Warsaw 2007.

11 J.J. Coyle, C.J. Jr. Langley, R.A. Novack, B.J. Gibson, Supply Chain Management. A Logistics Perspective, South Western College Pub., USA 2013. 
development and maintenance, to ultimately adopt a rational policy for various market segments.

In the light of the previous considerations referring both to the issues of the logistic level of customer service defined within the company and the analysis of elements implicating the formation of services from the point of view of the clients themselves, it is possible to indicate fundamental guidelines in the field of management of this area in business entities ${ }^{12}$. The process of proper management of the logistic customer service is analyzed by M. Christopher ${ }^{13}$, P.M. Price and N.J. Harrison ${ }^{14}$, A. Rushton, P. Croucher and P. Baker ${ }^{15}$, and they formulate the following criteria:

- identification of real market segments;

- identification of customer needs or identified demand within individual market segments;

- specification of measurable customer service standards;

- trade-off ${ }^{16}$ between different levels of customer service and their costs;

- measuring the services provided;

- contact with clients in order to indicate the evaluation of the performed services. The article further discusses the results of research on selected tasks of logistic management of customer service among the aforementioned, i.e. determination of clearly formulated, measurable customer service standards and communication with customers regarding their expectations for the level of services provided.

\section{Research methodology}

In order to identify selected tasks of logistic management of customer service in the operation of commercial cargo motor transport enterprises ${ }^{17}$ in the Silesian Voivodeship, primary research was carried out by the author. The cognitive method used was the survey method, in which the categorized technique of obtaining primary information was used - a questionnaire.

The survey was conducted among 147 enterprises of commercial cargo motor transport operating in the Silesian Voivodeship. As a result of obtaining, processing and analysis of the empirical material obtained in the survey using the questionnaire, the determinants of the scope of logistic customer service in the surveyed enterprises of commercial truck transport were presented.

Afterwards, taking into account the entirety of the conducted research procedure, based on the collected primary data, an attempt was made to examine the dependence of selected areas of logistic customer service, occurring in the surveyed enterprises of commercial cargo motor transport in the Silesian Voivodeship, on the size of these entities. For this purpose, for the analysis of primary

${ }_{12}$ M. Romanowska, Podstawy organizacji i zarzadzania, Difin Publisher, Warsaw 2001.

${ }_{13}$ M. Christopher, Logistics \& Supply...

14 P.M. Price, N.J. Harrison, Looking at logistics: a practical introduction to logistics, customer service, and supply chain management, Access Education, United Kingdom 2013.

15 A. Rushton, P. Croucher, P. Baker, The Handbook of Logistics \& Distribution Management, Kogan Page, London 2014.

${ }^{16}$ Cf. D. Kempny, Logistyczna obstuga klienta...

17 K. Wojewódzka-Król, E. Załoga, Transport. Nowe wyzwania, PWN, Warsaw 2016. 
data in the aspect of selected problems in the conducted statistical analysis, one of the most commonly used measures was the Pearson linear correlation coefficient, determined for correlation tables. This coefficient is defined by the formula ${ }^{18}$ :

$$
r_{x y}=\frac{\sum_{i=1}^{k} \sum_{j=1}^{l} n_{i j} \cdot\left(\dot{x}_{i}-\bar{x}\right) \cdot\left(\dot{y}_{j}-\bar{y}\right)}{\sqrt{\sum_{i=1}^{l} n_{i}\left(\dot{x}_{i}-\bar{x}\right)^{2} \sum_{j=1}^{k} n_{j}\left(\dot{y}_{j}-\bar{y}\right)^{2}}},
$$

where:

- the $x$ and $y$ features are presented on an ordinal scale,

$-n_{i j}$ means the number of cells corresponding to individual sets $x_{i} y_{j}$.

The use of an ordinal scale in the case of information available is possible in only a few cases, however the usefulness of this coefficient is also based on the lack of requirements for filling all cells of the correlation table. It is also postulated that due to the difficulty in assessing the severity of the assessment of the correlation coefficient, its statistical significance should be tested. For this purpose, the significance test of the correlation coefficient is used. In the case of these studies, the following hypotheses were always assumed ${ }^{19}$ :

$$
H_{0}: p=0, H_{1}: p \neq 0,
$$

whose test is the statistic:

$$
z=\frac{r_{x y}}{\sqrt{1-r_{x y}^{2}}} \cdot \sqrt{n},
$$

for $n \geq 122$, which assuming equity $H_{0^{\prime}}$, has a normal distribution $\rightarrow \mathrm{N}(0,1)$ and:

$$
t=\frac{r_{x y}}{\sqrt{1-r_{x y}^{2}}} \cdot \sqrt{n-2},
$$

which assuming equity $H_{0}$ has Student's t-distribution with n-1 degrees of freedom.

\section{Establishing logistic standards of customer service in the surveyed enterprises}

According to the analysis of the answers to the first two questions contained in the questionnaire form, micro entities dominated among 147 surveyed enterprises, which constituted $76 \%$ of the research population (112 enterprises). The share of small entities, constituting $16.5 \%$ of the total number of respondents ( 24 enterprises) was also significant. At the same time, medium-sized and large enterprises recorded a small share in the study, together constituting $7.5 \%$ of the research sample (11 enterprises).

18 S. Ostasiewicz, Z. Rusnak, U. Siedlecka, Statystyka - elementy teorii $i$ zadania, Wroclaw University of Economics Publisher, Wroclaw 2011.

19 M. Sobczyk, Statystyka, PWN, Warsaw 2017. 
Determination of clearly defined and measurable standards of logistic customer service in the surveyed business entities was an important issue of the research tool addressed to all $(\mathrm{N}=147)$ respondents. Respondents asked to indicate whether the elements of their logistic service were subject to standardization and if so, how many standards were established in the surveyed entities, most of them were granted by the lack of them - this was the answer of 51 entrepreneurs (34.7\%). The remaining 96 companies confirmed having established logistic service standards for their buyers, of which 33 entities $(22.4 \%)$ recorded one stated logistic service standard, 21 entities $(14.3 \%)$ recorded two standards and 36 entities $(24.5 \%)$ three standards. The number of entrepreneurs who established a greater number of standards of their logistic customer service was negligible: 3 companies $(2 \%)$ had from four to five standards, six to ten standards -2 economic units $(1.4 \%)$ and only one entity $(0.7 \%)$ declared above ten standards. Figure 1 presents the distribution of responses to the question about having established logistic customer service standards in the surveyed enterprises.

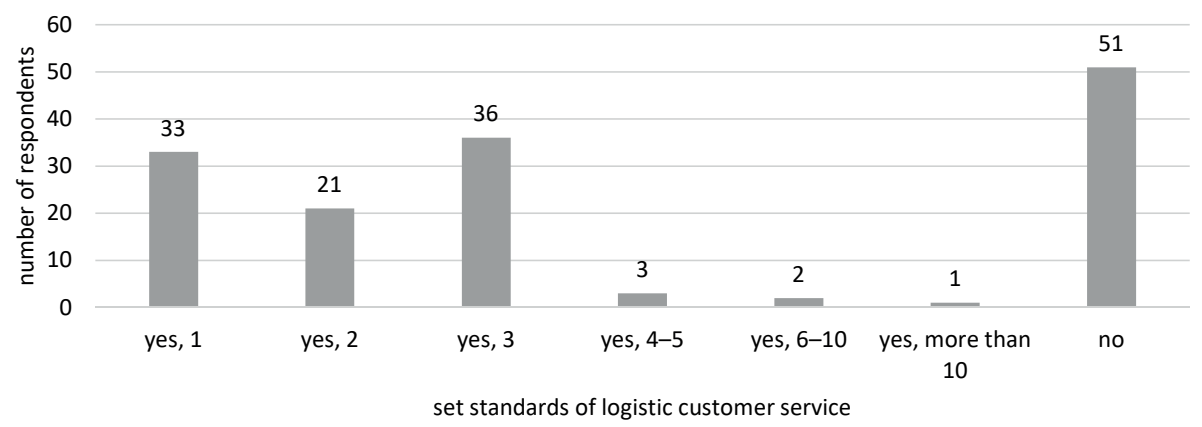

Figure 1. Having set standards of logistic customer service by the surveyed enterprises Source: own elaboration

The next question in the questionnaire was addressed to 96 respondents who, in response to the previous issue, confirmed having established logistic service standards for their buyers. Therefore, the size of the shares was determined in relation to the number of responses received, limited to 96 . Among entrepreneurs who declared having precise logistic customer service standards, as much as 75\% (72 entities) indicated full consideration of the expectations of their clients in determining the standardization of elements of this service. Up to $50 \%$ of buyers 'expectations in relation to the level of logistic service offered were taken into account only by 6 entities $(6.2 \%)$, and over $50 \%$ of buyers' expectations - by 16 entities (16.7\%). Two companies (2.1\%) admitted that their customers' expectations were not taken into account in relation to the level of logistics service offered. The distribution of responses received from the surveyed entrepreneurs to the question of taking into account the expectations of customers in relation to the level of logistic service offered in enterprises confirming the possession of established standards of this service, is presented in Figure 2. 


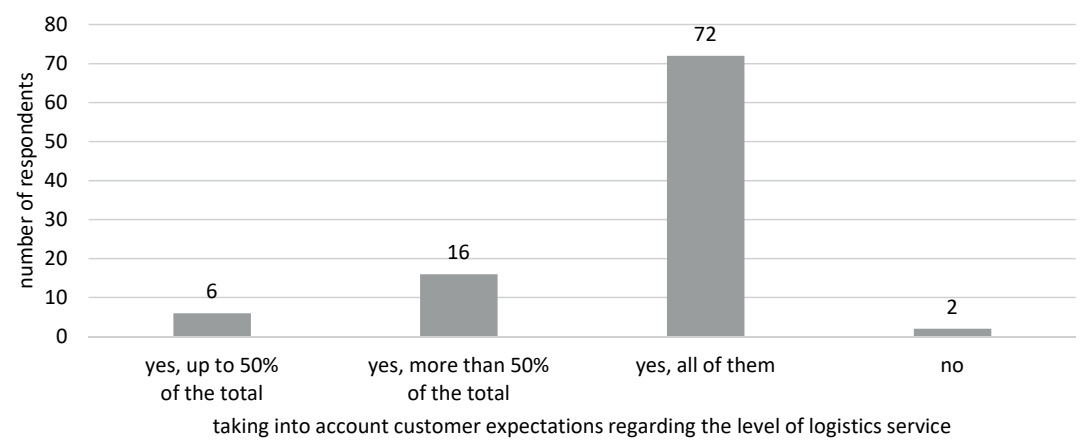

Figure 2. Taking into account customer expectations regarding the level of logistics services in enterprises confirming the possession of established standards of this service Source: own elaboration

\section{Standards of logistic customer service and the size of the surveyed enterprises}

The distribution of the number of logistic customer service standards in the surveyed enterprises depending on the size of enterprises is presented in Table 1. High level of correlation: 0.688 , indicates a greater tendency to determine a sufficiently high number of standards by large and medium enterprises in comparison with smaller units. The largest group of micro transport enterprises, $44.6 \%$, admitted the complete lack of established standards. Almost half of these enterprises and in relation to the whole sample over $1 / 3$ - are entities that recorded only one established standard of logistic service. This result confirms poorly demonstrated understanding for the needs related to the level of logistics service desired by customers and their viewpoint.

Table 1. Distribution of the number of logistic customer service standards in the surveyed enterprises depending on the size of enterprises

\begin{tabular}{|l|c|c|c|c|}
\hline \multirow{2}{*}{ Number of logistic customer service standards } & \multicolumn{5}{|c|}{ Type of enterprise } \\
\cline { 2 - 5 } & micro & small & medium & large \\
\hline no & 50 & 1 & 0 & 0 \\
\hline yes, 1 & 31 & 2 & 0 & 0 \\
\hline yes, 2 & 18 & 2 & 1 & 0 \\
\hline yes, 3 & 13 & 19 & 4 & 0 \\
\hline yes, $4-5$ & 0 & 0 & 3 & 0 \\
\hline yes, 6-10 & 0 & 0 & 0 & 2 \\
\hline yes, more than 10 & 0 & 0 & 0 & 1 \\
\hline
\end{tabular}

Source: own elaboration

Table 2 presents the distribution of respondents' responses to include the expectations of customers in relation to the level of logistic service in enterprises 
confirming the possession of established standards of this service, depending on the size of enterprises. Between consideration of defined standards and the size of the surveyed enterprises, there is a clear correlation at the level of 0.306 , which proves that the bigger the enterprise, the wider the opening to the expectations and proposals from the customers. Large enterprises, for example due to financial, organizational or HR resources, are able to realize more potential orders of various types. According to the presented research results, almost all companies that take into account the expectations of customers, implement them in most procedures. Only $8.3 \%$ of enterprises with established logistic service standards do not take these expectations into consideration or account for less than half of them.

Table 2. Considering customer expectations regarding the level of logistics services in enterprises confirming having established standards of this service depending on the size of enterprises

\begin{tabular}{|l|c|c|c|c|}
\hline If the company's logistic customer service standards & \multicolumn{4}{|c|}{ Type of enterprise } \\
\cline { 3 - 5 } $\begin{array}{c}\text { are set, do they take into account customer } \\
\text { expectations regarding the level of service? }\end{array}$ & micro & small & medium & large \\
\hline yes, up to 50\% of the total & 1 & 5 & 0 & 0 \\
\hline yes, more than 50\% of the total & 11 & 3 & 2 & 0 \\
\hline yes, all of them & 47 & 16 & 6 & 3 \\
\hline no & 2 & 0 & 0 & 0 \\
\hline
\end{tabular}

Source: own elaboration

\section{Conclusions}

A full understanding of the needs associated with having a wide range of logistic service standards, i.e. more than three basic standards, was shown by the least entrepreneurs - about $4 \%$. The lack of recognition of the need to recognize the expectations of buyers with regard to the level of individual elements of logistic service is alarming and close to $2 \%$ of the surveyed entities. Determination of clearly defined and measurable logistic customer service standards in the surveyed business entities obtained a similar distribution of responses, i.e. nearly $35 \%$ of respondents admitted not applying normalization of logistics service elements, but among entrepreneurs who declared having precise logistics service standards, as many as $75 \%$ indicated full taking into account the expectations of their clients.

The attempt to investigate the dependence of the scope of logistic customer service, occurring in the surveyed enterprises of commercial cargo motor transport in the Silesian Voivodship, on the size of these entities, brought satisfactory results in the majority of the phenomena considered. The analysis of primary data obtained from the respondents' answers to questions in the questionnaire, in relation to the size of the surveyed enterprises, with the use of selected statistical measures, confirmed statistically significant dependencies. Due to the small values of the obtained statistical measures, the conclusions included in the considerations are rather hypothetical, while the generalizations formulated on the basis of them can be considered as interesting research theses, constituting a contribution to further basic research. 
The observed diversification of the advancement of the logistics scope of customer service in the surveyed entities depends on many factors and one of the most important is the size of enterprises of commercial transport of cargoes. The establishment of large, medium, small and micro enterprises from the commercial cargo motor transport sector, their place on the market of transport services and development opportunities are the resultant of many external and internal conditions. The most important external factors are undoubtedly creation of reasonable conditions for the functioning of entities from the state policy, as well as the sphere of competition. Internal factors determining the framework for the activity of transport enterprises are primarily their economic and financial condition, which is expressed both in human resources, material, financial, IT, as well as the ability to manage them. The distribution of responses of respondents depending on the size of enterprises usually confirmed that with the increase in the size of the surveyed enterprises, they showed an increasing tendency to carry out the measurements mentioned above.

\section{References}

Ballou R.H., Business Logistics: Supply Chain Management, Prentice Hall, United Kingdom 2003. Bowersox D.J., Closs D.J., Cooper M.B., Supply Chain Logistics Management, McGraw Hill, United Kingdom 2009.

Chaberek M., Makro- $i$ mikroekonomiczne aspekty wsparcia logistycznego, University of Gdańsk Publisher, Gdańsk 2002.

Chopra S., Meindl P., Supply Chain Management: Strategy, Planning, and Operation, Person Prentice Hall, New Jersey 2009.

Christopher M., Logistics $\mathcal{E}$ Supply Chain Management, Financial Times Prentice Hall, Harlow 2011.

Cook S., Customer Care Excellence. How to Create an Effective Customer Focus, Kogan Page Ltd., London 2002.

Coyle J.J., Langley C.J. Jr., Novach R.A., Gibson B.J., Supply Chain Management. A Logistics Perspective, South Western College Pub., USA 2013.

Kempny D., Logistyczna obstuga klienta, PWE, Warsaw 2001.

Kisperska-Moroń D., Logistics customer service levels in Poland: changes between 1993 and 2001, International Journal of Production Economics 2005, 93-94.

Kramarz M., Elementy logistyczne obsługi klienta w sieciach dystrybucji, Difin Publisher, Warsaw 2014.

Nogalski B., Ronkowski R., Wspótczesne przedsiębiorstwo. Problemy funkcjonowania i zatrudniania, TNOiK, Warsaw 2007.

Ostasiewicz S., Rusnak Z., Siedlecka U., Statystyka - elementy teorii i zadania, University of Economics Publisher in Wroclaw, Wroclaw 2011.

Price P.M., Harrison N.J., Looking at logistics: a practical introduction to logistics, customer service, and supply chain management, Access Education, United Kingdom 2013.

Romanowska M., Podstawy organizacji i zarządzania, Difin Publisher, Warsaw 2001.

Rushton A., Croucher P., Baker P., The Handbook of Logistics E Distribution Management, Kogan Page, London 2014.

Sobczyk M., Statystyka, PWN, Warsaw 2017.

Wojewódzka-Król K., Załoga E., Transport. Nowe wyzwania, PWN, Warsaw 2016.

\section{Corresponding author}

Marta Kadłubek can be contacted at: martakadlubek@wp.pl 